\title{
Factors That Affect Students' Performance in College Algebra in Some Selected Colleges of Education in Ghana
}

\author{
Joseph Kofi Asiedu \\ Tutor, Department of Mathematics and ICT, Al - Faruq College of Education, Wenchi, Ghana \\ DOI: $10.29322 / I J S R P .10 .10 .2020 . p 10622$ \\ http://dx.doi.org/10.29322/IJSRP.10.10.2020.p10622
}

\begin{abstract}
This study sought to find out factors that affect the performance of pre-service teachers in college algebra in some selected Colleges of Education in the Bono Region of Ghana. A quantitative survey design was employed in this study. The study was conducted in two Colleges of Education and sixty - six (66) second-year pre-service teachers offering 4-year Bachelor of Education(B.Ed.) Programmes in both Primary and Junior High School ( JHS) education randomly selected. A five- point Likert scale questionnaire was used to collect data on the three factors (students' attitude, motivation, and lesson presentation). Twenty (20) items questionnaire was administered to the pre-service teachers to collect data. The data were analyzed and the descriptive statistics involving means and standard deviation as well as correlation, regression, and paired samples t-test were used to address the research questions. The findings revealed that the poor performance of students in college algebra in colleges of education in Ghana was caused by students' negative attitude, motivation and lesson presentation. It is, therefore, recommended that these negative attitude needs to be corrected by instilling in students the values in mathematics. Teachers teaching college algebra should be innovative and use the appropriate technique to teach the concepts in college algebra. The government and stakeholders in teacher education should provide necessary materials and other resources in colleges of education to harness the potentials of preservice teachers.
\end{abstract}

Index Terms- Factors, College Algebra, Performance

\section{INTRODUCTION}

P rimitive man had no opportunity for using sophisticated equipment and materials for building their shelters and construction of roads. There were no measuring instruments for measuring lengths and heights of their buildings but they were able to count, measure, locate, estimate, and calculate materials that would be used. Mathematics began when people started counting. The language as a cultural artefact manifests through the use of symbols and other representations.

Language acquisition plays a key role in concept formation. The symbolic representations in mathematics are the language which is communicated to the learners for the formation of mathematical concepts. Algebra is a branch of mathematics in which letters and other symbols are used to represent numbers and quantities or formulae and equations. Other branches of mathematics have some aspects of algebra in them. Algebra can be found in Geometry, Arithmetic, Transformation, calculus etc. Most in mathematics perceive algebra as a purely abstract form of mathematics and that it cannot be objectified. The perception of abstractness of algebra poses a challenge to learners understanding of the concept.

Most mathematical classroom discourses are full of symbolic representations and manipulations. The basic school mathematics curriculum is anchored on the area of algebra. Algebra has many aspects including symbols and expressions, linear equations, quadratic equations, relations and functions, algebra of polynomials, and combinatorics etc. The pre-service teachers at colleges of education in Ghana need to have sound knowledge in algebraic thinking.

Algebra serves as a bedrock to elementary school mathematics so its content and pedagogical knowledge are essential. According to Moses and Cobb (2001), algebra has proven to be a gatekeeper limiting some students' access to higher education and mathematically oriented careers. Many students admitted to the college of education in Ghana beset difficulties in algebra courses. Students find algebra courses challenging due to some factors which could have been avoided at the foundation level. The misconception in algebra has led to students' anxiety, fear, and attitudes. The dire consequence was the higher failure rates in college algebra and other courses in mathematics. According to Driscoll (1999), "Algebraic thinking has three central habits of mind: the doing - undoing, building rules to represent functions, and abstracting from the computation.

Mathematics as a mother of all subjects is being taught in all areas of Ghanaian educational settings. The Basic school pupils especially crèche start their day with identification of geometric objects in the classroom. Pre - number activities which provide the basis for children to acquire early number concepts and foundations of later skills in mathematics need to be handled by a competent and experienced teacher. The meaningful mathematics understanding is through communication by symbolic representations.

Ghana has forty-six (46) public colleges of education whose core mandate is to train teachers for both JHS and Primary schools. The entry requirements for Colleges of Education in Ghana are not different from public Universities.

The Public Colleges of Education have over the years trained teachers for both Primary and Junior High Schools. The 
Colleges train student - teachers in various subjects' curricula including Mathematics. Before someone can teach mathematics at the basic level, he/she needs to be taught the content (which is the subject matter or concept) and the pedagogy (which is the teaching skills, styles, procedures etc.). The Mathematics Pedagogical Content Knowledge is the authority of every Mathematics teacher. Elementary and college algebra is the course being offered by preservice teachers in colleges of education in Ghana. Algebra I and Algebra II are the courses in mathematics that are taught in the first year, the first semester of the B.Ed. Four - year programmes in the colleges of education in Ghana. According to Chief Examiner's report from the Institute of Education, the University of Cape Coast, students' performance in these two algebra courses was abysmal in 2018/2019 academic year-end - of - the firstsemester examination. There were high standard deviations associated with the mean scores of Algebra I (12. 46\%) and Algebra II (12.45\%).

The prospective teachers from some Colleges of Education failed willfully in both courses. The problem emanated from the elementary school level and continue to be the dominant factor for poor performances of students in mathematics. Student's perceptions of algebra at the secondary school level alluded to their understanding of mathematical concepts at the college level. There is a wide gap between the students' transition from number concepts to algebraic concepts in mathematics. The variables that influence students' performance in college algebra courses in the Colleges of Education in Ghana are both inside and outside the school. These factors affect greatly the learners' performance in mathematics, especially algebra.

Problem-solving is the heart of every subject and ability to model the problem from a different perspective in mathematics develops the cognition in an individual. The word problems in mathematics must be modelled into mathematical language. According to Mayer and Wittrock (2006), problem-solving is a cognitive process directed at achieving a specific goal when no solution method is at hand for students.

The teacher's content and pedagogical knowledge in algebra are vital for the development of students' algebraic thinking skills. Teachers and students attitudes, the availability and adequate teaching and learning materials and other resources determine the performance level or the level of development of algebraic thinking. The students understanding of unknowns (variables) in algebra is intuitively developed to coordinate "letters" or literal symbols. "The fact that literal symbols can represent unknowns sometimes interfere with students' ability to understand situations where they represent quantities that vary (Malisani and Spagnolo, 2009). Students' algebraic thinking skills slow down because it is more difficult to take the letter ' $\mathrm{x}$ ' as a variable if one is used to working only in a context where it represents specific unknown. Students conceive symbols as an abstract entity and so if they are used to represent the unknowns or variables, then there is no objectivity in Algebra.

The performance of pre-service teachers in algebra at Colleges of Education in Ghana is a major concern to stakeholders in education. The successfulness of algebraic thinking problem is the substance on_immeasurable of factors. Students, teachers and school factors have a bearing on the learning of mathematics. The study seeks to examine pre-service teachers' factors that influence their performance in College Algebra. It also sought to explore school-based factors that affect students' performance in College Algebra in some selected colleges of education in Ghana.

Research on factors that influence the pre-service teachers' performance in college algebra in Colleges of Education in Ghana is a serious issue in teacher education in Ghana. The teachers teaching mathematics at the basic level must have in-depth mathematical knowledge in both content and pedagogy. The study sought to examine the following questions:

1. What factors affect students' performance in College Algebra?

2. What influence do students' 'Entry Grades' have on their College Algebra performance?

3. What impact do students and school factors have on students' college algebra performance?

4. What are possible effects of the use of TLMs (ICT tools. i.e. CAS) on teaching and learning of College Algebra?

\section{REVIEW OF RELATED LITERATURE}

The variables to be studied were the students' factors and school factors. The factors are the independent variables while the students' performance is the dependent variable. Students' performance in college algebra in Colleges of Education in Ghana depend on these important thematic areas. The school factor and student factors.

The figure below shows some possible relevant factors that influence students' performance in College Algebra 


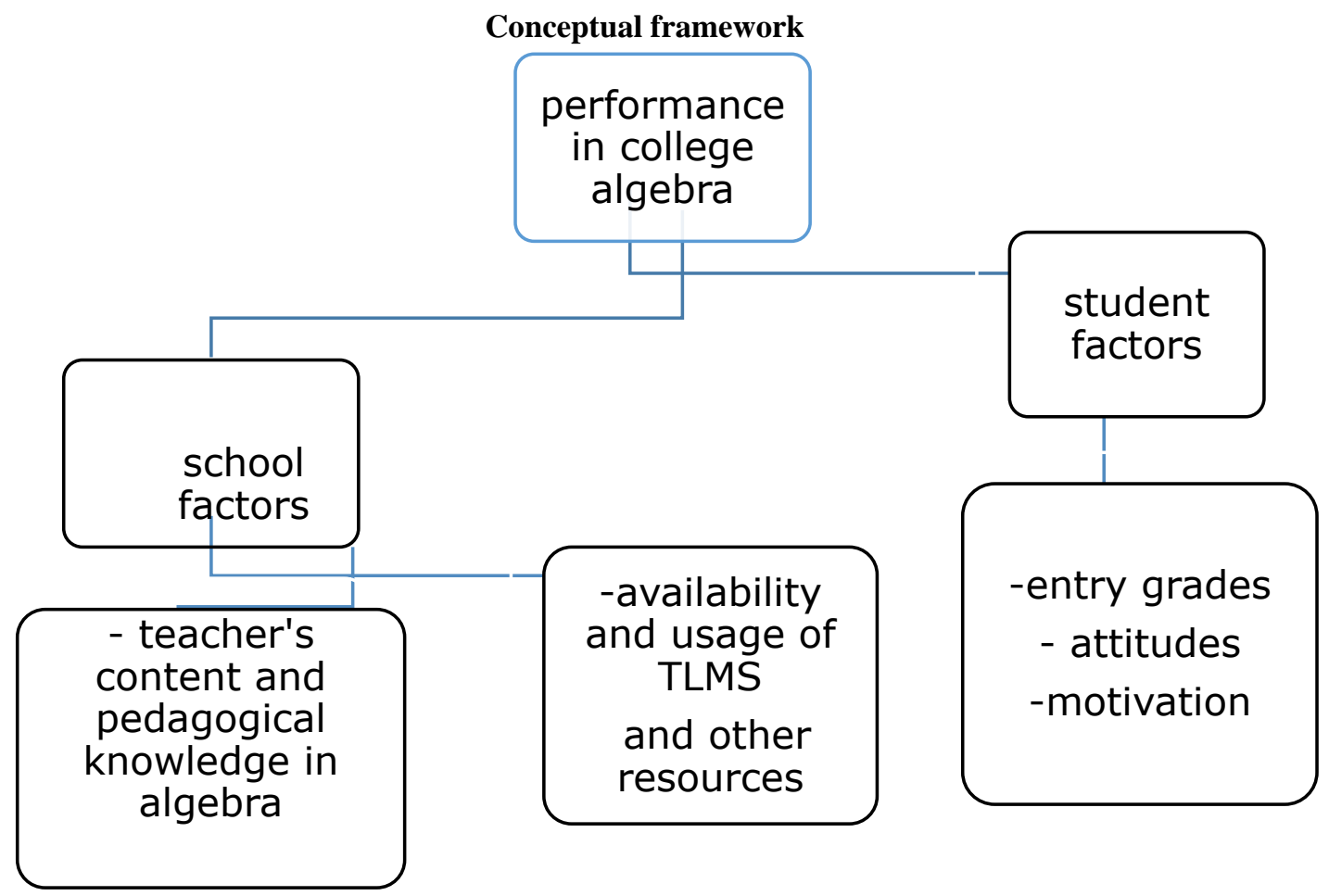

Figure 1: factors affecting students' performance in College Algebra

\subsection{Students Attitudes towards College Algebra}

The attitudes of pre-service teachers towards mathematics especially College Algebra influence their performance. Students' perception and beliefs about the competence and expectations in school directly connected to their engagement levels, as well as to the emotional states that promote or interfere with their ability to be academically successful (National Research Council, 2000; as cited in Akey (2006) and Enu (2015)).

The attitudes of students determine the extent to which the concept of algebra would be learned. Students with positive attitudes put in more effort in learning the concept and they excel always in mathematics due to their active participation in the lesson. Mathematics teachers achieve their stated objectives when students develop positive attitudes towards the lesson. Algebra is about doing and students who developed a passion and interest in it, understand the concept relationally.

\subsection{Motivation}

Students become more active and excited to interact with the learning environment when they are inspired. Teachers can instil the interest of mathematics in students when they are allowed to personally involve in the lessons. Students' motivation in mathematics both intrinsic and extrinsic bring about their meaningful learning in the classroom. Motivation, both intrinsic and extrinsic, is a key factor in the success of students at all levels of their education (Teach thought teachers, 2017).

According to J.S. Farrant (1968), lack of motivation on the part of both teachers and students contribute to poor performance. Mathematics teacher's motivation in the subject helps to bring an effective classroom discourse. Teachers who are motivated enough are more excited and poised to teach mathematics with the passion to harness the potentials of students in College Algebra. The role of the teacher affects the interest of the students both positively or negatively in College Algebra. Parents and peers interaction in mathematics offload the negative perceptions about mathematics thereby increasing the students' participation in the lesson.

\subsection{Teaching and Learning Resources}

Effective teaching and learning of mathematics can be achieved with the availability and use of materials and resources. Teaching resources play a significant role in learning. According to Ankomah (1998), cited in Enu (2015), "effective teaching and learning greatly lied on the competences of its human resources as well as material resources which were needed for the impartation of knowledge".

The use of modern computer-based technology in teaching algebra helps to bring about functional algebraic concepts on the part of students

\subsection{Teacher's Content and Pedagogical Knowledge}

Teachers play an essential role in inculcating the academic standards to students. These standards can be achieved when the teachers who are facilitating the students' learning are grounded in both the content and pedagogical knowledge in mathematics. An effective mathematics teacher is the one who has a mastery of the subject matter and knows how to impart to students using the teaching and learning resources to bring out the innate potentialities of the learners.

Teachers teaching College Algebra in the College of Education should possess the remarkable mathematical traits for meaningful delivery of the lesson. Mathematics teachers' content 
knowledge, teaching style motivates students and spark their curiosity in learning the tasks. Most students learn greatly through the lesson presented by the teacher. The attitudes and motivation of students are determined largely by teacher factors.

\section{Methodology}

The population for the study comprises all Colleges of Education in the Bono and Ahafo Regions of Ghana. However, the sample consisted of sixty - six (66) pre-service teachers selected randomly from two Colleges of Education from the Bono Region. The study would use descriptive statistics in which a survey research design would be adopted. The instrument that would be used for the study is a survey questionnaire that measured students' attitudes, motivation, teaching and learning resources, and teacher's knowledge in college algebra. The five (5) point Likert scale questionnaire made of twenty (20) items. Seven (7) of the items measured students' attitude towards college algebra, Eight (8) items measured motivation, and lesson presentation seven (7) items. For checking the internal consistency for each scale, the reliability statistics report from SPSS output showed that Cronbach's Alpha values of: students' attitude $(\mathrm{N}=7)=.727$, motivation $(\mathrm{N}=8)=.766$, and lesson presentation $(\mathrm{N}=7)=.727$. The Cronbach alpha coefficient above .7 is acceptable (DeVellis, 2003).

Data that was collected from students' response questionnaires were coded and analyzed using SPSS. Descriptive statistics involving means and standard deviation as well as inferential statistics involving correlation, regression, and pair sample t-test statistics were used to address the research questions.

\subsection{Participants}

The participants for the study were 66 pre-service teachers in two selected Colleges of Education in the Bono Region of Ghana. The students in the second year were given 5 points Likert scale survey questionnaires consisting of 20 items.

\section{RESULTS/FINDINGS}

The results from students' questionnaires showed the possible factors in the Colleges of Education that may affect the performance of students in College Algebra. The 66 selected students from the two colleges of Education for the study were asked to indicate which of their opinions towards College Algebra course in a five (5) point Likert scale. In the twenty (20) items, measuring students' attitudes, motivation, teaching resources and lesson presentation.

The students' response questionnaires on the item statements on their attitude towards college algebra, motivation and lesson presentation (school factors) were analyzed descriptively and their means and standard deviations are summarized in the table in table7 at Appendix I. The means and standard deviations of descriptive statistics on school and students factors shown in table 1 below.

Table 1: Descriptive statistics of overall Means and Std. Deviations of students' response to the factors that affect students' performance in College Algebra $(\mathrm{N}=66)$

\begin{tabular}{lccc}
\hline \multicolumn{2}{c}{ FACTORS } & Mean & Std. Deviation \\
\hline \multirow{2}{*}{ Students' factor } & Students' Attitude & 2.2619 & .69517 \\
& Motivation & 2.4139 & .68954 \\
School factor & Lesson presentation & 2.1667 & .60432 \\
& & & \\
\hline
\end{tabular}

\subsection{Students' Attitudes towards college algebra}

The sampled pre-service teachers for the study were asked of their views on classroom mathematics discourse and their performance in college algebra. The responses from the students helped to detect the particular kind of attitudes that affected their performance. The results showed that $53.1 \%$ with $($ Mean $=1.58)$ indicated that they strongly disagree $(15.2 \%)$ and disagree $(37.9 \%)$ on the statement 'I like symbols, they do make me think always in mathematics lessons'. The statement 'I learn algebra well on my own' $51.5 \%$ with $($ Mean $=1.88)$ stated that they strongly disagree $(27.3 \%)$ and disagree $(24.2 \%)$. Again $50 \%$ with $($ Mean $=2.17)$ responses of students indicated that they learn algebra well with the used of projectors. However, the majority of students indicated that they like college algebra. The statement 'I learn mathematics well when it is presented step by step in class', $87.9 \%$ with (Mean

This publication is licensed under Creative Commons Attribution CC BY

http://dx.doi.org/10.29322/IJSRP.10.10.2020.p10622
$=3.11)$ indicated that they agree $(47.0 \%)$ and strongly agree $(40.9 \%)$.

Comparing the mean responses with the overall mean score (Mean $=2.2619$ and $\mathrm{SD}=0.69517$ ) of students' attitude showed that the majority of students had a positive attitude towards college algebra.

\subsection{Motivation}

The sixty - six (66) sampled second-year college of education students were asked to indicate what motivates them to study college algebra. The responses from students showed that $66.7 \%$ of students indicated they Agree (45.5\%) and Strongly Agree $(21.2 \%)$ with $(\mathrm{M}=2.56, \mathrm{SD}=1.242)$ to the statement of motivation by parents; $77.3 \%$ indicated they Agree (47.0\%) and Strongly Agree $(30.3 \%)$ with $(\mathrm{M}=2.91, \mathrm{SD}=1.077)$ on teacher's motivation. More than $50 \%$ of the students indicated that they are 
motivated to learn college algebra with the use of audio-visual materials, Agree (53.0\%) and Strongly Agree (19.7\%) with ( $\mathrm{M}=$ 2.68, SD 01.139 ). From the descriptive statistics in table 1, students' motivation had overall ( $\mathrm{M}=2.4129, \mathrm{SD}=0.68954)$. The means for the three statements above were greater than $(\mathrm{M}=$ 2.4129 ). Therefore, parents, teachers, and TLMs motivates students and enhance their understanding of college algebra.

\subsection{Lesson presentation}

The students' response to questionnaires on lesson presentation was about the teacher's pedagogical content knowledge and teaching and learning resources. From table 1, the descriptive statistics showed the overall Mean $=2.1667$ and Standard Deviation $=.60432$. Out of 66 students, 87.9\% Agree $47.0 \%)$ and Strongly Agree (40.9\%) with ( $\mathrm{M}=3.11, \mathrm{SD}=1.111)$ indicated that their teachers present the algebra lessons well with the use of TLMS. 72.7\% indicated that they Agree ( 53.0\%) and Strongly Agree (19.7\%) to the statement on the use of visual and manipulative materials. Most students who indicated they want group work and discussions in college algebra class were $80.3 \%$, Agree $(40.9 \%)$ and Strongly Agree (39.4\%) with ( $\mathrm{M}=3.03$, SD $=1.095)$.

Opare (1999) also asserted that the provision of the needed human and material resources goes a long way to enhance academic performance. Ankomah (1998) noted that effective teaching and learning greatly lied on the competences of its human resources as well as material resources which were needed for the impartation of knowledge

Table 2: The performance grades of students in WASSSCE core mathematics and college algebra

\begin{tabular}{lccc}
\hline \multicolumn{2}{c}{ WASSCE } & Core Mathematics & \multicolumn{2}{c}{$\begin{array}{c}\text { College Algebra } \\
\text { Grade }\end{array}$} & Freq $(\boldsymbol{\%})$ & Grade & Freq $(\boldsymbol{\%})$ \\
\hline $\mathrm{A} 1$ & $2(3.03)$ & $\mathrm{A}$ & $8(12.12)$ \\
$\mathrm{B} 2 / \mathrm{B} 3$ & $28(42.42)$ & $\mathrm{B} / \mathrm{B}+$ & $7(10.61)$ \\
$\mathrm{C} 4$ & $11(16.67)$ & $\mathrm{C} / \mathrm{C}+$ & $22(33.33)$ \\
$\mathrm{C} 5 / \mathrm{C} 6$ & $25(37.88)$ & $\mathrm{D} / \mathrm{D}+$ & $18(27.27)$ \\
& & $\mathrm{E}$ & $11(16.67)$
\end{tabular}

Table 3 above showed the pre-service teachers' entry grades in WASSSCE core mathematics into public colleges of education in Ghana. The cut-off point was $\mathrm{C} 6$ and the number of students who entered with C5/C6 was 25 representing 37.88\%. Out of 66 students, only two (2) entered with A1 (3.03\%). After the first semester examination, $8(12.12 \%)$ of students had $\mathrm{A}$ and
11(16.67\%) had E (Fail). The results from the table show that students entered the college of education with good grades. However, 11(16.67\%) of them failed in college algebra examination at the end of the first semester.

Table3: Relationship between College performance and WASSCE core mathematics grades, students' attitudes, students' motivation, and lesson presentation $(\mathrm{N}=66)$

\begin{tabular}{|c|c|c|c|c|c|}
\hline & & $\begin{array}{l}\text { WASSCE } \\
\text { Core mathematics grade }\end{array}$ & Students' attitude & $\begin{array}{l}\text { Students } \\
\text { motivation }\end{array}$ & $\begin{array}{l}\text { Lesson } \\
\text { presentation }\end{array}$ \\
\hline College & Algebra Pearson & & & & \\
\hline \multirow[t]{2}{*}{ Grade } & Correlation & $.271^{*}$ & $.381^{* *}$ & $.434^{* *}$ & $.414^{* *}$ \\
\hline & Sig.(2-tailed) & .028 & .002 & .000 & .001 \\
\hline
\end{tabular}

*. Correlation is significant at the 0.05 level (2-tailed).

**. Correlation is significant at the 0.01 level (2-tailed).

From table 3, the correlation between the performance of college algebra (dependent variable) and independent variables (core mathematics; students' attitude; students' motivation; and lesson presentation). The relationship between college algebra performance and core mathematics is very weak (i.e., $r=0.271$ ) and significant at $\rho=0.028<0.05$ level $(2-$ tailed $)$

The correlation between the college algebra performance and the factors: students' attitude, students' motivation, and teacher lesson 
presentation were moderate with $(\mathrm{r}=0.381, \rho=0.002 ; \mathrm{r}=0.434$, $\rho=0.000 ;$ and $\mathrm{r}=0.414, \rho=0.001$ respectively).

Table4: Regression analysis showing Impact of Students and school factors on College algebra performance $(\mathrm{N}=66)$

\begin{tabular}{|c|c|c|c|c|c|}
\hline $\mathrm{R}$ & $\mathrm{R}$ - Square & F (Sig.) & $\begin{array}{l}\text { Standardized } \\
\text { Coefficient }\end{array}$ & $\mathrm{t}$ & Sig. \\
\hline \multirow[t]{3}{*}{.438} & .192 & 4.914(0.004) & -.113 & -.398 & 692 \\
\hline & & & .425 & 1. 230 & .223 \\
\hline & & & 122 & .406 & .686 \\
\hline
\end{tabular}

A regression analysis model was used to explore how well students' attitude; motivation and teacher lesson presentation could predict students' performance in college algebra. The regression equation with all the three predictors was significantly related to college algebra performance with an $R^{2}$ of $0.192, \mathrm{~F}(3$, $62)=4.914, \rho=0.004)$. The standardized coefficients of the three factors (predictors) were -. 113, 0. 425 and 0.122 for students' attitude, motivation, and teacher lesson presentation in that order. The standardized coefficients in the regression modelled in the equation below:

College Algebra Performance $=-.113 S A+0.425 S M+$ $0.122 T L P$, where SA means students' attitude, SM means students ' motivation and TLP means teacher lesson presentation.
The factors in the model above showed that students' motivation appeared to be a strong predictor of college algebra performance while teacher lesson presentations and students' attitude appeared to be quite acceptable. The negative sign of students' attitude indicates it has an impact on the students 'college algebra performance. When the students' attitude increases, it tends to decrease their performance in college algebra. It is also clear that there is a positive relationship between the dependent variable (college algebra performance) and the independent variables, (students' motivation; Teacher lesson presentation). Students' motivation has the strongest impact on the performance of students in college algebra with a significant value of 0.004 . The regression analysis verified that the $F$-value was significant indicating that the independent variables predict the dependent variable (see Table 5)

Table 5: Paired sample t-test of grades of College algebra and WASSSCE Core mathematics

\begin{tabular}{lccccccc}
\hline Performance & $\mathrm{N}$ & Mean & SD & Effect size & t- value & df & p - value \\
\hline College algebra grade & 66 & 60.26 & 11.047 & & & & \\
Core mathematics grade & 66 & 64.77 & 6.930 & & -3.235 & 65 & 0.002 \\
\hline
\end{tabular}

Analysis from the table7 shows there is a significant difference between the WASSSCE core mathematics grades (Mean $=64.77, \mathrm{SD}=6.930)$ and College algebra grades $($ Mean $=$ $60.26, \mathrm{SD}=11.047)$, with $\mathrm{t}(65)=-3,235, \rho-$ value $=0.002$. Since $0.002<0.05$, there was any evidence to suggest that a significant difference exists between the College algebra grades and WASSSCE core mathematics grades. WASSSCE core mathematics does not have any effect on college algebra. There was a statistically significant decrease in performance grades. The mean decrease was 4.515 with 95\% Confidence Interval ranging from -7.302 to -1.728 . The calculated eta square statistic $(0.14)$ indicates a large effect size (i.e.14\%) of the variance in college is explained by core mathematics. Therefore the performance of students in college algebra was not largely influenced by their WASSSCE mathematics grades.

\section{DISCUSSION}

The results from the data analysis showed that the students' factors: students' attitude and motivation greatly affect the performance of students in college algebra. The students' attitude contributes to the poor performance of students in college algebra. The students' attitude affected performance. Students who developed a bad attitude towards the course college algebra performed poorly in the semester examination. The more the students' attitude the more the decline of performance in 
mathematics. Motivation is the driving wheel to any success in mathematics, especially algebra. The students' motivation from parents, school, teachers, peers, reinforce their learning of mathematics at the college level. The students' entry grades in WASSSCE core mathematics into public colleges of education do not affect the performance of students in college algebra through $8(12.12 \%)$ out of 66 students had grade A. The entry cut-off point was $\mathrm{C} 6$ but at the end -of -first-semester examination in $2018 / 2019$ academic year 11(16.67\%) of 66 students had E (Fail).

The regression modelled equation showed the negative Standardized coefficient $(\mathrm{r}=-.113)$ of students' attitude and correlation coefficient of 0.381 is very small as compared with motivation and teacher lesson presentations. The mean and standard deviation of WASSSCE core mathematics performance was better than college algebra (Table 6). The weak correlation coefficient $(0.271, \rho=0.028)$ between performance in college algebra and core mathematics attest to the fact that students entry grades do not have an impact on college algebra performance.

The availability and the use of teaching and learning materials (TLMs) such as computer algebra system (CAS), computer Excel, projectors, and other computer applications help to promote and enhance teaching and learning of college algebra in colleges of education in Ghana. Teacher's content and pedagogical knowledge in college algebra is a key to meaningful teaching of the course.

\section{CONCLUSION AND RECOMMENDATIONS}

This study sought to explore students' personal and school factors that affect the performance of college algebra in some selected colleges of education in Bono Region of Ghana.

The results from the analysis clearly showed that poor performance of students in college algebra in colleges of education in Ghana was not affected by their entry grades. However, the students' attitude towards college algebra contributed to the poor performance at the end - of - semester examination. The students' entry grades, attitude, and motivation constitute the student factors while the teacher lesson presentation (teacher's pedagogical content knowledge and availability and use TLMs) constitute school factors. Students learn best when they are motivated by their parents, teachers, and peers. The application of technology to teaching and learning of college algebra, using Excel application for drawing linear and quadratic functions, calculators and other materials help teachers to impart the concept to learners in the classroom. Instructional materials motivate students and encourage them to study lesson providing them with the opportunity to have access to information and to evaluate it (Akkoyunlu (2002).

In conclusion, it was found out that the poor performance of students in college algebra in colleges of education in Ghana was as a result of students' negative attitude, motivation and lesson presentation. It is, therefore, recommended that these negative attitude needs to be corrected by instilling in students the values in mathematics. Again teachers should be innovative and use the appropriate technique to teach the concepts in college algebra. Furthermore, teachers are encouraged to develop a positive attitude in their students to enhance their understanding and passion for mathematics. The government and stakeholders in teacher education should provide necessary materials and other resources in colleges of education to harness the potentials of preservice teachers.

\section{REFERENCES}

[1] Ankomah, Y.A. (2002). The Success of Private basic Schools in Ghana. The case of three schools in Cape Coast. Journal of Educational Management (4), 14

[2] Asomah et al (2019).Ghanaian public and private junior high school mathematics classroom learning environment: A look at students' attitudes. African Journal of Educational Studies in Mathematics and Sciences Vol. 15, 2019

[3] Akkoyunlu, B. (2002). Educational Technology in Turkey: Past, Present and Future. Educational Media International 2 (39), 165-174

[4] Cobb, P., \& Steffe, L. P. (1983). The constructivist researcher as teacher and model builder. Journal for Research in Mathematics Education, 14(2), 83-94.

[5] Cobb, P., \& Yackel, E. (1996). Constructivist, emergent, and sociocultural perspectives in the context of developmental research. Educational Psychologist, 31(3-4), 175-190

[6] Cohen et al (2007, 6th. Ed). Research Methods in Education. Taylor \& Francis e-Library, 2007

[7] Driscoll (1999). Teaching Mathematics in Grade 6 - 12: Developing Research-Based. https://books.google.com.gh.books

[8] Driscoll(1999). Developing Algebraic Habits of Mind. A framework for Classroom Questions Aimed at Understanding Students Thinking. Courses.edtechleaders.org.patterns

[9] Enu, et al (2015) Factors Influencing Students' Mathematics Performance in Some Selected Colleges of Education in Ghana. International Journal of Education Learning and Development Vol.3, No.3.

[10] Farrant J.S. (1968). Principles and Practice of Education. Bristol, Western Printing services

[11] Malisani and Spagnolo (2009). From arithmetical thought to algebraic thought. The role of the "variable." Edu. Stud Math (2009). Springer Science + Business Media B .V 2008

[12] Moses and Cobb (2001). Radical equations: math literacy and civil rights. Boston: Beacon press

[13] TeachThought Staff(2017). Simple Ideas to Improve Student Motivation. https://www.teachthought.com.pedagogy

[14] Pallant J.( 2010, 4th ed.). SPSS Survival Manual: A step by step guide to data analysis using SPSS.

[15] McGraw - Hill Education

\section{AUTHORS}

First Author - Joseph Kofi Asiedu, Tutor, Department of Mathematics and ICT, Al - Faruq College of Education, Wenchi, Ghana, Email: kofimama97@yahoo.com 
APPENDIX I

Table 6: Mean Scores and Standard Deviations of items on the scale of the factors by school and students subscales

\begin{tabular}{lcc}
\hline \multicolumn{1}{c}{ Statement } & Mean & Std. Deviation \\
\hline I like doing mathematics because of algebra & 1.94 & 1.021 \\
I like symbols, they do make me think always in mathematics lessons & 1.58 & .978 \\
College Algebra is a course which is very interesting to me and I enjoy it & 2.33 & 1.155 \\
I like translating stories into literal symbols and letters in mathematics & 1.94 & 1.036 \\
I liked mathematics because of letters(x and y) & 1.95 & .902 \\
Algebra is an aspect of mathematics which I do better in an & & \\
examination than other aspects. & 2.08 & 1.219 \\
I feel easy working problems in algebra courses & 2.42 & 1.151 \\
I do much better in algebra courses when they are presented with & 1.91 & 1.262 \\
manipulative materials & 2.47 & 1.205 \\
I find it easy to translate word problems into algebraic symbols & 2.68 & 1.139 \\
I find algebra lessons interesting when working with visual materials & 1.97 & 1.176 \\
I always feel comfortable during mathematics lesson & 3.03 & 1.095 \\
I enjoy algebra lessons when working in groups & 2.35 & 1.222 \\
I find it interesting to represent a quantity by a symbol & 3.11 & 1.111 \\
I learn mathematics well when it is presented step by step in class. & 2.35 & 1.398 \\
I do relate any word problems in mathematics to real-life situations & 2.56 & 1.242 \\
My parents provide me a set of materials for learning mathematics & 2.17 & 1.090 \\
I learn algebra well with the used of projectors & 1.88 & 1.183 \\
I learn algebra well on my own & 2.91 & 1.077 \\
My teacher explains the concepts well during algebra lessons & 2.41 & 1.467 \\
I do better in mathematics when working with friends & & \\
& & \\
\hline
\end{tabular}

APPENDIX II

Table7: Paired Samples Correlation, Means, and Standard Deviations Statistics of students' college algebra and Core mathematics grades

\begin{tabular}{lcccc}
\hline & Mean & Std. Deviation & Correlations & Sig. \\
\cline { 2 - 5 } College algebra grade & 60.26 & 11.047 & & .028 \\
Core mathematics grade & & & .271 & \\
\hline
\end{tabular}

